\title{
Wip1 regulates SKOV3 cell apoptosis through the p38 MAPK signaling pathway
}

\author{
YANPING FENG ${ }^{1}$, FANG LIU ${ }^{1}$, ZHIXIANG DU ${ }^{1}$, DONGJIE ZHAO ${ }^{3}$, JIANXIN CHENG ${ }^{2}$ and WEI GUO ${ }^{1}$ \\ ${ }^{1}$ Department of Reproductive Medicine, The First Hospital of Hebei Medical University, Shijiazhuang, Hebei 050031; \\ ${ }^{2}$ Department of Obstetrics and Gynecology, The Fourth Hospital of Hebei Medical University, Shijiazhuang, Hebei 050000; \\ ${ }^{3}$ Department of Surgery, The Third Hospital of Tangshan, Tangshan, Hebei 063100, P.R. China
}

Received January 8, 2016; Accepted January 19, 2017

DOI: $10.3892 / \mathrm{mmr} .2017 .6469$

\begin{abstract}
The aim of the present study was to explore the effect of silencing wild-type p53-induced phosphatase 1 (Wip1) on apoptosis of human ovarian cancer SKOV3 cells. SKOV3 cells cultured in vitro were divided into three groups: untreated cells, cells transfected with control small interfering RNA (siRNA) and cells transfected with siRNA targeting Wip1. Flow cytometry analysis was used to detect cell apoptosis. Western blot analysis was performed to determine expression of tumor protein 53 (p53), cleaved caspase-3, caspase-3, BCL2 associated X (Bax), BCL2 apoptosis regulator ( $\mathrm{Bcl}-2)$, p38 mitogen-activated protein kinase (p38 MAPK) and phosphorylated (p)-p38 MAPK. Reverse transcription-quantitative polymerase chain reaction was used to detect expression of p53, Bax, Bcl-2 and caspase-3 mRNAs. Compared with control, apoptosis of SKOV3 cell was significantly increased following Wip1 siRNA silencing. Wipl silencing also resulted in a significant increase of p53 and p-p38 MAPK expression, as well as increased cleaved caspase-3/caspase-3 and Bax/Bcl-2 protein ratios. No significant differences were observed in apoptosis and apoptosis-related protein expression in the control siRNA transfected cells. The present study demonstrated that Wip1 silencing promotes apoptosis of human ovarian cancer SKOV3 cells by activation of the p38 MAPK signaling pathways and through subsequent upregulation of p53, and cleaved caspase-3/caspase-3 and Bax/Bcl-2 protein ratios. Overall, the findings of the present study suggest that targeting Wip1 may be a potential therapeutic avenue for the treatment of human ovarian cancer in the future.
\end{abstract}

Correspondence to: Professor Jianxin Cheng, Department of Obstetrics and Gynecology, The Fourth Hospital of Hebei Medical University, 12 Jiankang Road, Shijiazhuang, Hebei 050000, P.R. China

E-mail: 15031176518@163.com

Key words: ovarian cancer, wild-type p53-induced phosphatase 1, human ovarian cancer SKOV3 cells, apoptosis

\section{Introduction}

Ovarian cancer, one of the most common gynecologic malignancies, is an insidious cancer with a 5-year survival rate of merely $20-30 \%$ (1). Currently, the pathogenesis of ovarian cancer remains incompletely understood. Apoptosis is a highly regulated, crucial biological process leading to cell death: Regulatory imbalance can cause excessive cell proliferation or apoptosis, leading to diseases including ovarian cancer. Several studies have demonstrated that abnormal apoptosis regulation in ovarian cells contributes to the development of ovarian cancer $(2,3)$. Wild-type p53-induced phosphatase 1 [Wip1; official name: protein phosphatase, $\mathrm{Mg} 2+/ \mathrm{Mn} 2+$ dependent 1D (PPM1D)], a p53-dependent proto-oncogene first identified in 1997 (4), is widely involved in the regulation of multiple cell signaling pathways, and is important in the pathogenesis of cancers, including ovarian cancer (5-7).

Previous studies have demonstrated that Wip1 is closely associated with apoptosis. Ma et al (8) revealed that manganese $(\mathrm{Mn})$ exposure led to neuronal necrosis in rats, accompanied by a significant increase in neuronal apoptosis and a notable reduction in Wip1 expression in nerve tissues and cells. Sun et al $(9,10)$ reported that Wip1 expression was significantly higher in nasopharyngeal cancer and renal cancer tissues than in normal tissues. Wip1 silencing led to a markedly accelerated apoptosis in these types of cancer cells, indicating involvement of Wip1 in suppressing apoptosis. By contrast, elevated Wip1 expression exhibits an inhibitory effect on apoptosis (8-10). To the best of our knowledge, the mechanism by which Wip1 regulates apoptosis in ovarian cancer cells has not been reported to date.

The present study aimed to investigate in vitro the role of Wip1 in apoptosis of ovarian cancer SKOV3 cells and its potential mechanism of action.

\section{Materials and methods}

Cell culture. The human ovarian cancer cell lines SKOV3, CAOV3, AZ780, ES2 and the normal ovarian epithelial cell line were purchased from Cell Center, Peking Union Medical College (Beijing, China). They were cultured in Dulbecco's modified eagle's medium-1640 supplemented with $5 \%$ fetal bovine serum (FBS), 2 mM l-glutamine, $100 \mathrm{U} / \mathrm{ml}$ penicillin 
and $100 \mu \mathrm{g} / \mathrm{ml}$ streptomycin in an atmosphere containing $95 \%$ air, $5 \% \mathrm{CO}$. Cells were plated $\left(1 \times 10^{3}\right.$ cells/well $)$ in 96 -well plates for $24 \mathrm{~h}$ and incubated at $37^{\circ} \mathrm{C}$ for $4 \mathrm{~h}$ in 3-(4,5-dimethythiazol-2-yl)-2,5-diphenyltetrazolium bromide (MTT), which was purchased from Sigma-Aldrich; Merck KGaA (Darmstadt, Germany). The medium was removed, $50 \mu \mathrm{l}$ DMSO was added to each well and incubated at room temperature for $45 \mathrm{~min}$ while shaking. Absorbance was measured at a wavelength of $570 \mathrm{~nm}$, using a SynergyMx microplate reader (Bio Tek Instruments, Inc., Winooski, VT, USA) to determine the viable cell fraction.

Cells at a 75-85\% confluence were either left untreated, transfected with Wip1 siRNA plasmid or control siRNA plasmid which was performed with Lipofectamine ${ }^{\circledR} 2000$ (Invitrogen; Thermo Fisher Scientific, Inc., Waltham, MA, USA) according to the manufacturer's protocol, and then collected for experimental assay $48 \mathrm{~h}$ following transfection.

Antibodies and siRNAs. Antibodies towards Wip1 (cat. no. D4F7), p38 mitogen-activated protein kinase (p38 MAPK; cat. no. 9212), phosphorylated (p-) p38 MAPK (Thr180/Tyr182; catalog no. 3D7), tumor protein 53 (p53; cat. no. 7F5), mitogen-activated protein kinase 1 (ERK; cat. no. 137F5), phosphorylated (p-) ERK (Thr202/Tyr204; cat. no. D13.14.4E), mitogen-activated protein kinase 8 (JNK; cat. no. 56G8), phosphorylated (p-) JNK (Thr183/Tyr185; cat. no. G9) and cleaved caspase-3 (cat. no. 9661) and the MAPK inhibitor SB203580 were purchased from Cell Signaling Technology, Inc. (1:1,000; Danvers, MA, USA). Mouse anti-BCL2 (cat. no. ab7923) associated X (Bax; cat. no. ab77566) monoclonal antibody, rabbit anti-BCL2 apoptosis regulator (Bcl-2; cat. no. ab7973), caspase-3 (cat. no. ab32499) antibody were diluted at 1:1,000 and purchased from Abcam, Cambridge, UK. Pro-Light horseradish peroxidase chemiluminescence detection reagents were purchased from Tiangen Biotech Co., Ltd. (Beijing, China). siRNAs were purchased from Sigma-Aldrich; Merck KGaA. siRNA sequences were as follows: Wip1 siRNA-1, 5'-UUG UGAGUGAGUCGAGGUCGUUUCC-3'; Wip1 siRNA-2, 5'-UAUCCUUAA AGUCAGGGCUUUAGCG-3'; Wip1 siRNA-3, 5'-CCTCACAGCGAAAGAACTCTGTTAA-3'; and control non-targeting N-siRNA, 5'-GAGUGGGUCUGGGUC UUCCCGUAGA-3'.

Apoptosis analysis by Annexin V-fluorescein isothiocyanate (FITC)/propidium iodide (PI) staining. Apoptotic cells in different groups were determined using an Annexin V/PI apoptosis detection kit according to the manufacturer's protocol (Multi Sciences Biotech Co., Ltd., Hangzhou, China). Briefly, the cell pellet was resuspended in $1 \mathrm{x}$ binding buffer followed by incubation with $5 \mathrm{ml}$ of Annexin V (conjugated with FITC) and $10 \mathrm{ml}$ of PI, in the dark for $5 \mathrm{~min}$. Cell fluorescence was then analyzed using a flow cytometer (Epics-XLII, Becman Coulter, Inc., Brea, CA, USA). This test discriminates intact cells (Annexin V-/PI-), early apoptotic cells (Annexin V+/PI-) and late apoptotic cells (Annexin $\mathrm{V}+/ \mathrm{PI}+$ ).

Western blot. Cells were lysed in lysis buffer for $2 \mathrm{~h}$ on ice. Confluent cell layers were washed with PBS and lysed for $30 \mathrm{~min}$ at $4^{\circ} \mathrm{C}$ with $1 \%$ Nonidet P-40, $0.1 \%$ Triton $\mathrm{X}-100$, $30 \mathrm{mM}$ sodium phosphate ( $\mathrm{pH} 7.4)$ containing $1 \mathrm{mM}$ sodium orthovanadate, $2.5 \mathrm{mM}$ Tris- $\mathrm{HCl}$ (pH 7.5), $100 \mathrm{mM} \mathrm{NaCl}$, and $10 \mu \mathrm{g} / \mathrm{ml}$ of leupeptin, aprotinin. Following centrifugation at $13,000 \mathrm{x} \mathrm{g}$ for $20 \mathrm{~min}$ at $4^{\circ} \mathrm{C}$, the supernatant was collected. Protein concentration was measured using a Lowry protein assay. Total cell lysates (40 $\mu \mathrm{g}$ protein) were separated by polyacrylamide $10 \%$ SDS-PAGE gels, and electrotransferred to a polyvinylidene fluoride membrane. The membrane was blocked by incubation with $0.05 \%$ nonfat milk powder in TBST for $2 \mathrm{~h}$ at $37^{\circ} \mathrm{C}$, and then primary antibodies to cleaved caspase-3, caspase-3, p53, p38 MAPK, p-p38 MAPK, Bax and Bcl-2 were added for incubation overnight at $4^{\circ} \mathrm{C}$. Following washing, the membrane was incubated with horseradish peroxidase-labeled goat anti-mouse or rabbit secondary antibody (1:5,000 dilution in TBST containing 1\% bovine serum albumin; Santa Cruz Biotechnology, Inc., Dallas, TX, USA) for $120 \mathrm{~min}$ at room temperature and then washed three times with TBST at $37^{\circ} \mathrm{C}$. Finally, blots were visualized by chemiluminescence and autoradiography. LabWorks 4.5 analysis software (UVP, Inc., Upland, CA, USA) was used to perform quantification of bands in the western blots.

Reverse transcription-quantitative polymerase chain reaction $(R T-q P C R)$. Total RNA was extracted using TRIzol (Thermo Fisher Scientific, Inc., Waltham, MA, USA) and reverse transcribed. Total RNA $(2 \mu \mathrm{g})$ was reverse transcribed using random primers and M-MLV at $42^{\circ} \mathrm{C}$ for $1 \mathrm{~h}$ and then heated to $94^{\circ} \mathrm{C}$ for $5 \mathrm{~min}$ in a total reaction volume of $20 \mu \mathrm{l}$. Equal amounts of the product of the reverse transcription reaction were subjected to PCR amplification. qPCR was performed at a final volume of $20 \mu \mathrm{l}$, with $20 \mu \mathrm{l}$ SYBR Premix Ex TaqTM II (2X; Takara Bio, Inc., Otsu, Japan), $0.4 \mu 1$ ROX Reference Dye (50X; Takara Bio, Inc.), $2 \mu \mathrm{l}$ reverse transcription cDNA, $0.8 \mu \mathrm{l}$ of mixed forward and reverse primers (at a final concentration of $1 \mathrm{ng} / \mathrm{ml}$ ) and $6 \mu \mathrm{l}$ double-distilled water. The reaction was performed for 40 cycles as follows: $95^{\circ} \mathrm{C}$ for $30 \mathrm{sec}, 95^{\circ} \mathrm{C}$ for $5 \mathrm{sec}, 55^{\circ} \mathrm{C}$ for $30 \mathrm{sec}$ and $72^{\circ} \mathrm{C}$ for $30 \mathrm{sec}$. Relative fold changes in mRNA expression were calculated using the $2^{-\Delta \Delta \mathrm{Cq}}$ method (11). Primer sequences were as follows: Bax, forward 5'-GCTTGCTTCAGGGTTTCATCCA-3' and reverse 5'-TGT CCACGGCGGCAATCATC-3'; Bcl-2, forward 5'-GGCGGA GAACAGGGTACGATAAC-3' and reverse 5'-CGGGAT GCGGCTGGATGGGG-3' ; p53, forward 5'-CTAACCGCG GTCCCTTCCCAGAAAACCTAC-3' and reverse 5'-TACAGT CAGAGCCAACCTCAGGCG-3'; caspase-3, forward 5'-AAT GTCATCTCGCTCTTGGT-3' and reverse 5'-GCTTAGAAT CACACACAC-3';18S ribosomal RNA, forward 5'-ACACGG ACAGGATTGACAGA-3' and reverse 5'-GGACATCTAAGG GCATCACAG-3'.

Statistical analysis. Experimental data were expressed as the mean + standard deviation. Statistical analysis was performed with the SPSS 13.0 statistical software (SPSS, Inc. Chicago, IL, USA). One-way analysis of variance was followed by Dunnett's test for multiple comparisons. $\mathrm{P}<0.05$ was considered to indicate a statistically significant difference.

\section{Results}

Screening of ovarian cancer cell lines. Wip1 expression was analyzed in various ovarian cancer cells lines by RT-qPCR 


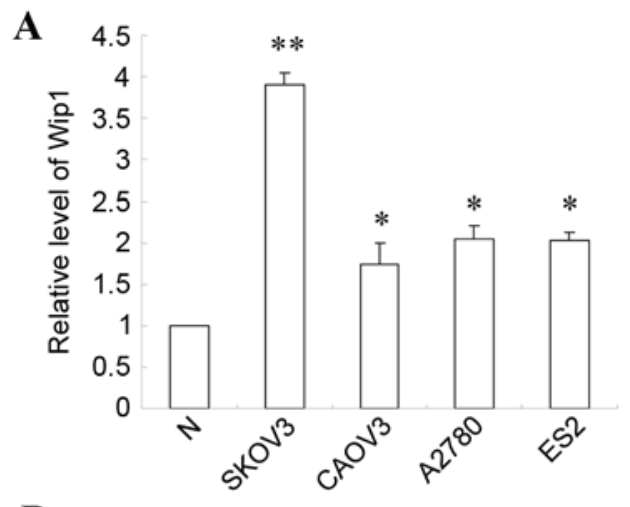

B
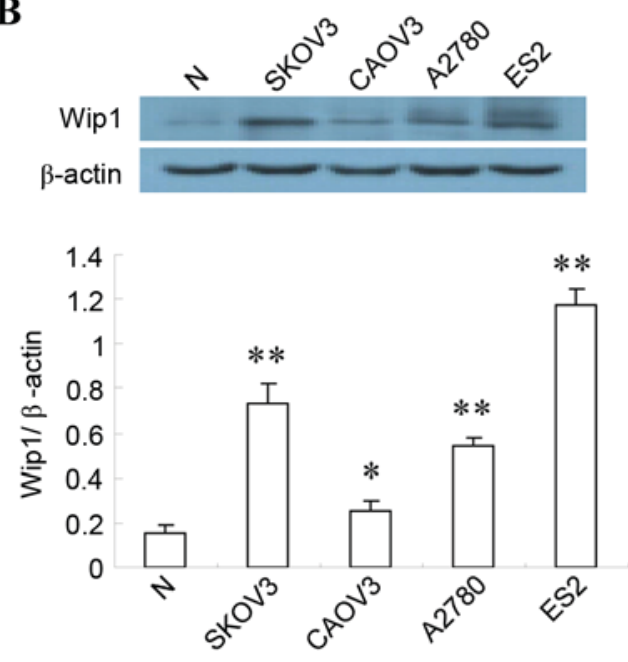

Figure 1. Expression of Wip1 in ovarian cancer cell lines SKOV3, CAOV3, A2780, ES2 and ovarian epithelial cell line. (A) Wip1 mRNA expression levels were assessed by reverse transcription-quantitative polymerase chain reaction. Results are plotted relative to normal control $(n=6)$. (B) Western blot analysis of Wip1 protein expression levels with quantification relative to $\beta$-actin control $(\mathrm{n}=6) .{ }^{*} \mathrm{P}<0.05$ and ${ }^{* *} \mathrm{P}<0.01$ vs. N. Wip1, wild-type p53-induced phosphatase $1 ; \mathrm{N}$, ovarian epithelial cell line.

and western blotting. Both mRNA and protein expression levels of Wip1 were significantly elevated in SKOV3, CAOV3, AZ780 and ES2 cells ovarian cancer cell lines compared with normal (ovarian epithelial cell line), indicating that overexpression of Wip1 is a feature of ovarian cancer cells (Fig. 1). Expression of Wip1 mRNA and protein was significantly higher in SKOV3 cells than in the other three cell lines (Fig. 1). Consequently, SKOV3 cells were selected to further explore the relationship between Wipl and ovarian cancer.

Wipl silencing by siRNA on SKOV3 cells. In order to efficiently silence expression of Wip1 in SKOV3 cells, three different siRNA sequences were tested, as well as various conditions for the transfection. As demonstrated in Fig. 2A, reduced Wip1 protein expression was observed in SKOV3 cells following siRNA transfection, compared with untransfected cells, with siRNA-2 being the most efficient. Wip1 protein expression was decreased in Wip1 siRNA-2 transfected cells compared with control, reaching the lowest level at $80 \mathrm{nmol} / \mathrm{l} \mathrm{siRNA}$ (Fig. 2B) and at $48 \mathrm{~h}$ following transfection (Fig. 2C). Assessment of cell viability by MTT assay demonstrated that SKOV3 cells were still viable following Wipl siRNA transfection, proliferation was significantly decreased compared to control $(\mathrm{P}<0.01$, Fig. 2D).

Effect of Wipl silencing on apoptosis of SKOV3 cells. Assessment of apoptosis by Annexin V/PI staining revealed a significant increase in SKOV3 apoptosis following Wip1 silencing by siRNA, compared with control untransfected cells (Control; $\mathrm{P}<0.01$, Fig. 3), or with non-targeting siRNA transfected cells (N-siRNA; $\mathrm{P}<0.01$, Fig. 3 ). The apoptosis rate of SKOV3 cells was similar in both the control untransfected cells and the non-targeting siRNA transfected cells.

Effect of Wipl silencing on mRNA expression of apoptosis-related proteins. To gain insight into the mechanism of SKOV3 apoptosis caused by Wip1 silencing, the expression of apoptosis-related proteins Bax, caspase-3, p53 and Bcl-2 was examined. Upon Wip1 silencing, relative expression of

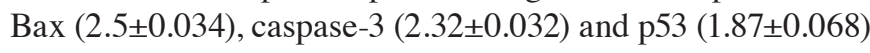
mRNA was significantly higher in SKOV3 cells transfected with Wipl siRNA, compared with control ( $\mathrm{P}<0.01$; Fig. 4A). The relative expression of $\mathrm{Bcl}-2$ mRNA $(0.47 \pm 0.035)$ was significantly reduced compared with control ( $\mathrm{P}<0.05$; Fig. 4A), resulting in an increased $\mathrm{Bax} / \mathrm{Bcl}-2$ ratio. The mRNA expression of apoptosis-related proteins did not differ significantly in the control untransfected cells and the cells transfected with the non-targeting siRNA (data not shown). The above findings suggested that silencing Wip1 promoted expression of pro-apoptotic markers in SKOV3 cells.

Effect of Wipl silencing on SKOV3 apoptosis-related protein expression. Protein expression of apoptosis-related markers Bax, cleaved caspase-3, caspase-3, p53 and Bcl-2 was detected by western blotting (Fig. 4B). In SKOV3 cells, expression of $\mathrm{Bax} / \mathrm{Bcl}-2$ protein ratio $(0.86 \pm 0.041)$, cleaved caspase-3/caspase- 3 protein ratio $(0.78 \pm 0.031)$ and $\mathrm{p} 53$ protein $(1.02 \pm 0.051)$ was significantly higher in Wipl siRNA cells than control $(0.38 \pm 0.059$; $\mathrm{P}<0.01$; Fig. $4 \mathrm{~B})$. There were no significant differences in expression of apoptosis-related proteins in the control untransfected cells (Control) compared with the cells transfected with the non-targeting siRNA (N-siRNA; Fig. 4B). These results indicated that silencing Wip1 promoted expression of pro-apoptotic proteins in SKOV3 cells.

Wipl acts through the p38 MAPK signaling pathway. Following Wipl silencing, expression of the major signaling molecules ERK, p-ERK, JNK, p-JNK, p38 MAPK and p-p38 MAPK was analyzed by western blot. The results demonstrated a significant increase in p-p38 MAPK protein $(\mathrm{P}<0.05$, Fig. 5A), suggesting involvement of p38 MAPK signaling in the Wip1-mediated apoptosis effect in SKOV3 cells. To confirm this, the p38 MAPK inhibitor SB203580 was utilized to block p38 MAPK signaling: Treatment with SB203580 significantly reduced p38 MAPK phosphorylation $(\mathrm{P}<0.01$, Fig. 5B). Assessment of cell proliferation by MTT assay revealed that SB203580 treatment completely reversed the proliferation-inhibition effect of Wip1 silencing in SKOV3 cells, suggesting that p38 MAPK is the main mediator of this effect $(\mathrm{P}<0.01$, Fig. 5C). Based on these findings, Wip1 silencing promoted SKOV3 apoptosis by regulating the p38 MAPK pathway. 

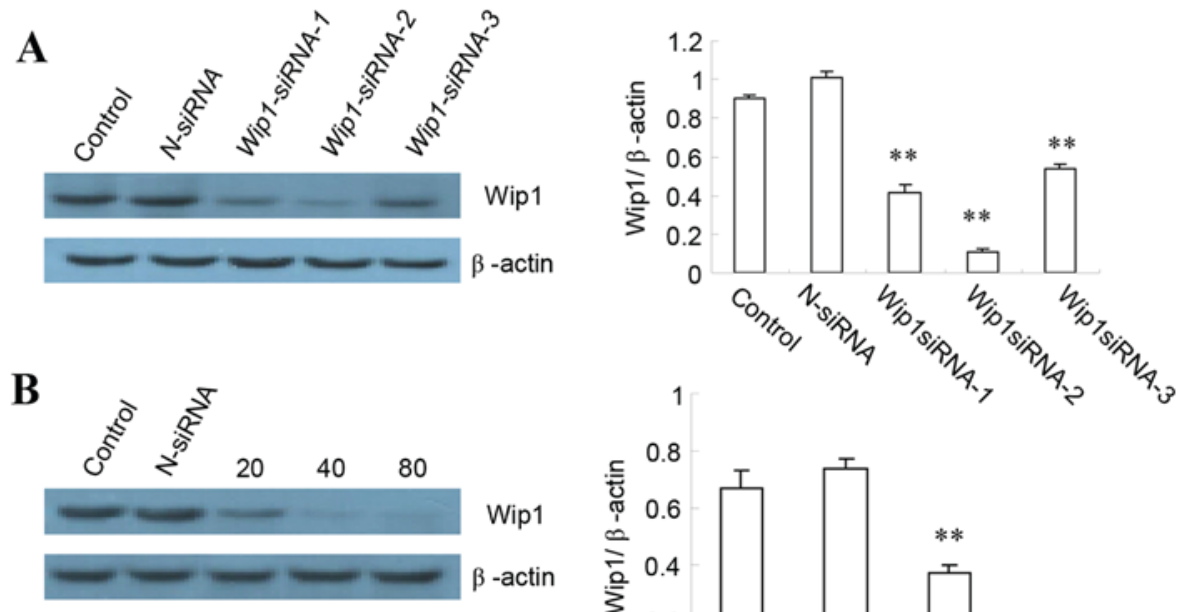

C
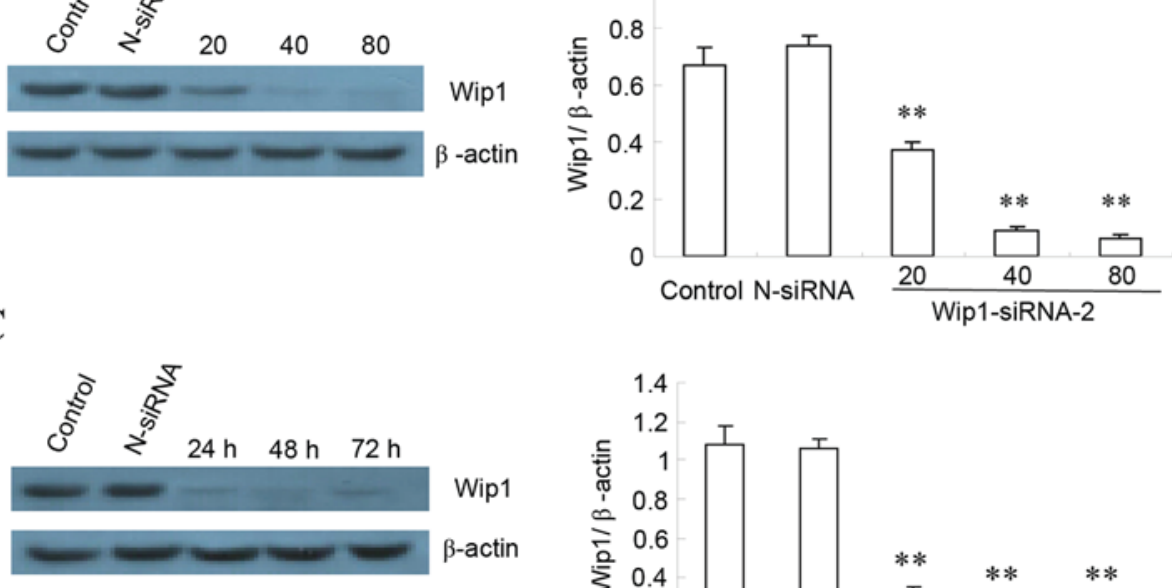

D
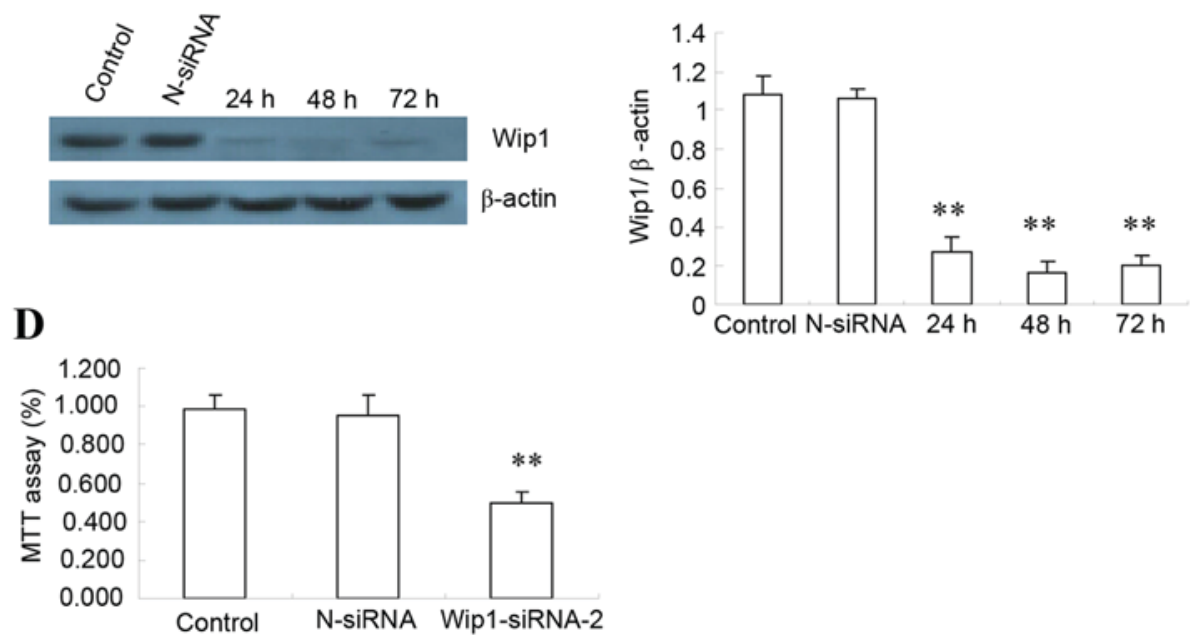

Figure 2. Wip1 silencing by siRNA in SKOV3 ovarian cancer cells. (A) Wip1 protein expression levels were assessed by western blotting in untransfected cells (Control) and cells transfected with either N-siRNA or one of the three different siRNA sequences (siRNA-1, -2 or -3), with quantification relative to $\beta$-actin. (B) SKOV3 cells were either left untransfected (Control) or transfected with either N-siRNA or with 20, 40, or $80 \mathrm{nmol} / 1$ Wip1-siRNA-2. The effect on Wip1 expression was analyzed by western blot. Representative images and quantification is reported here as fold ratio to $\beta$-actin. (C) SKOV3 cells were either left untransfected (Control) or transfected with either N-siRNA or Wip1-siRNA-2 (80 nmol/1 Wip1-siRNA-2), for 24, 48 or $72 \mathrm{~h}$. The effect on Wip1 expression was analyzed by western blot. Representative images and quantification is reported here as fold ratio to $\beta$-actin. (D) SKOV3 cells were either left untransfected (Control) or transfected with either N-siRNA or Wipl-siRNA-2 ( $80 \mathrm{nmol} / 1$ Wipl-siRNA-2 for $48 \mathrm{~h}$ ), and the proliferation rate was analyzed by MTT assay (n=4 repeats). ${ }^{* *} \mathrm{P}<0.01$ vs. Control. Wip1, wild-type p53-induced phosphatase 1; siRNA, small interfering RNA; N-siRNA, non-targeting siRNA.

A

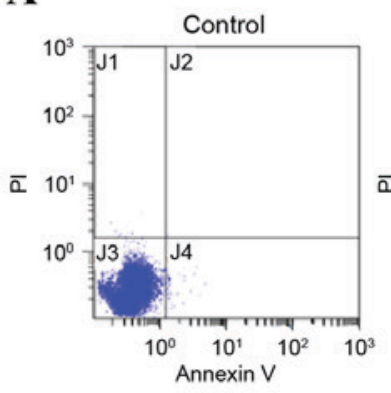

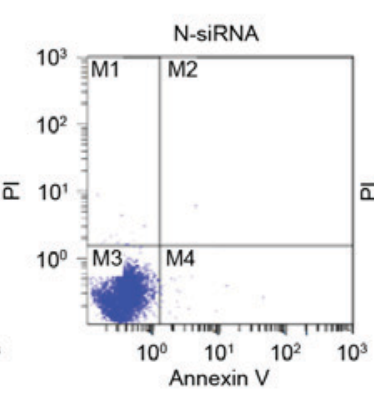

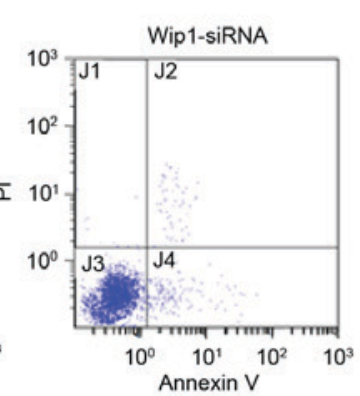

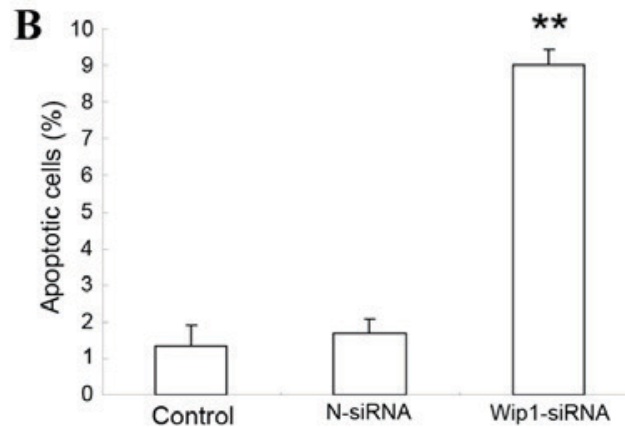

Figure 3. Effect of Wip1 siRNA on SKOV3 cell apoptosis. SKOV3 cells were either left untransfected (Control) or were transfected with either N-siRNA or Wipl-siRNA, following which they were analyzed for apoptosis by Annexin V-FITC/PI staining and flow cytometry. (A) Representative flow cytometry plots. Apoptotic cells were divided into two stages: early apoptotic (Annexin $\mathrm{V}^{+} / \mathrm{PI}^{-}$, J4 quadrant) and late apoptotic (Annexin $\mathrm{V}^{+} / \mathrm{PI}^{+}$, J2 quadrant) cells (B) Quantification of flow cytometry analysis, reporting results for the early and late apoptotic cells as \% of total population analyzed (n=4 repeats). ${ }^{* *} \mathrm{P}<0.01$ vs. Control. Wip1, wild-type p53-induced phosphatase 1; siRNA, small interfering RNA; N-siRNA, non-targeting siRNA; FITC, fluorescein isothiocyanate; PI, propidium iodide. 


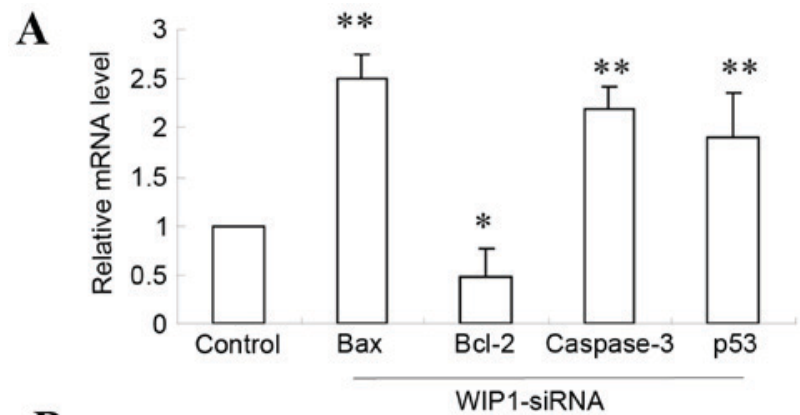

B
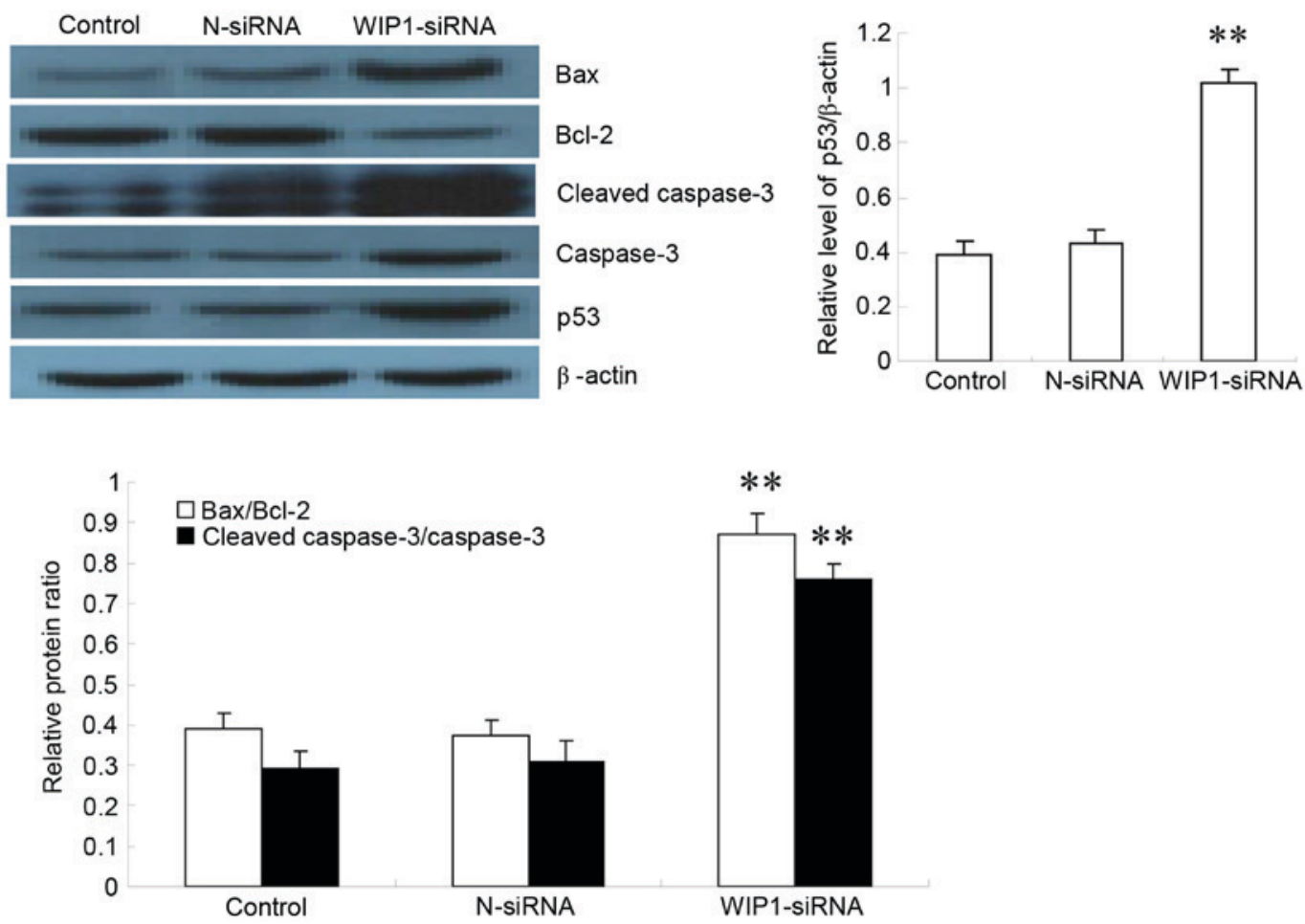

Figure 4. Effect of Wip1 siRNA on expression of apoptotic markers in SKOV3 cells. (A) The mRNA expression levels of Bax, Bcl-2, caspase-3 and p53 were analyzed by reverse transcription-quantitative polymerase chain reaction in SKOV3 cells transfected with Wip1 siRNA and control untransfected cells ( $\mathrm{n}=6$ ). Results are plotted relative to the control. (B) The protein levels of Bax, Bcl-2, cleaved caspase-3, caspase-3 and p53 were analyzed by western blot (n=6 repeats). Results for 553 are plotted relative to $\beta$-actin, and for the other proteins as ratios of Bax/Bcl-2 expression and of cleaved caspase-3/caspase-3 expression. ${ }^{*} \mathrm{P}<0.05$ and $^{* *} \mathrm{P}<0.01$ vs. Control. Wip1, wild-type p53-induced phosphatase 1; siRNA, small interfering RNA; Bax, BCL2 associated X; Bcl-2, BCL2 apoptosis regulator; $\mathrm{p} 53$, tumour protein 53; N-siRNA, non-targeting siRNA.

\section{Discussion}

Previous studies have suggested that Wip1 may be important in regulation of treatment response in malignant tumors. Lee et al (12) revealed a significant increase in UV-induced apoptosis by Wip1 knockout in mice or human keratinocytes. A Wip1 inhibitor, CCT007093, has also been reported to increase apoptosis in breast cancer cells and skin keratinocytes (12). A previous study by Yang et al (13) assessed tumor specimens derived from breast cancer patients for Wip1 mRNA and protein expression using semi-quantitative RT-PCR, immunohistochemistry and western blotting, and demonstrated that expression of Wip1 was significantly higher in breast cancer tissues than in adjacent, normal breast tissues. High expression of Wip1 mRNA and protein may therefore promote breast cancer growth, suggesting that may be a novel target for breast cancer therapy. Thus, regulation of Wip1 levels may also be a potential treatment of ovarian cancer.
Wip1, a serine/threonine protein phosphatase located in human chromosome region 17q23/q24, is encoded by the gene protein phosphatase $\mathrm{Mg} 2+/ \mathrm{Mn} 2+$ dependent 1D (PPM1D). The Wip1 gene is commonly overexpressed or amplified in human cancers, including primary breast cancers (14-16), gastric cancers (17), medulloblastomas (18-20), neuroblastomas (21), and ovarian clear cell adenocarcinomas (5,22). Previous studies have demonstrated a close association between Wipl genes and apoptosis $(23,24)$. Apoptosis is a process of programmed cell death, regulated by a balance of anti-apoptotic factors (such as Bcl-2) and pro-apoptotic factors (such as p53, Bax and caspase-3). The interaction between pro-apoptotic and anti-apoptotic factors is closely associated with the pathogenesis and development of tumors. Song et al (25) reported a significant increase in Wip1 levels following $\gamma$-irradiation in prostate cancer cells. In these cells, Wip1 interacted with and dephosphorylated Bax, resulting in Bax translocating to the mitochondria and inhibiting apoptosis. The study also 
A
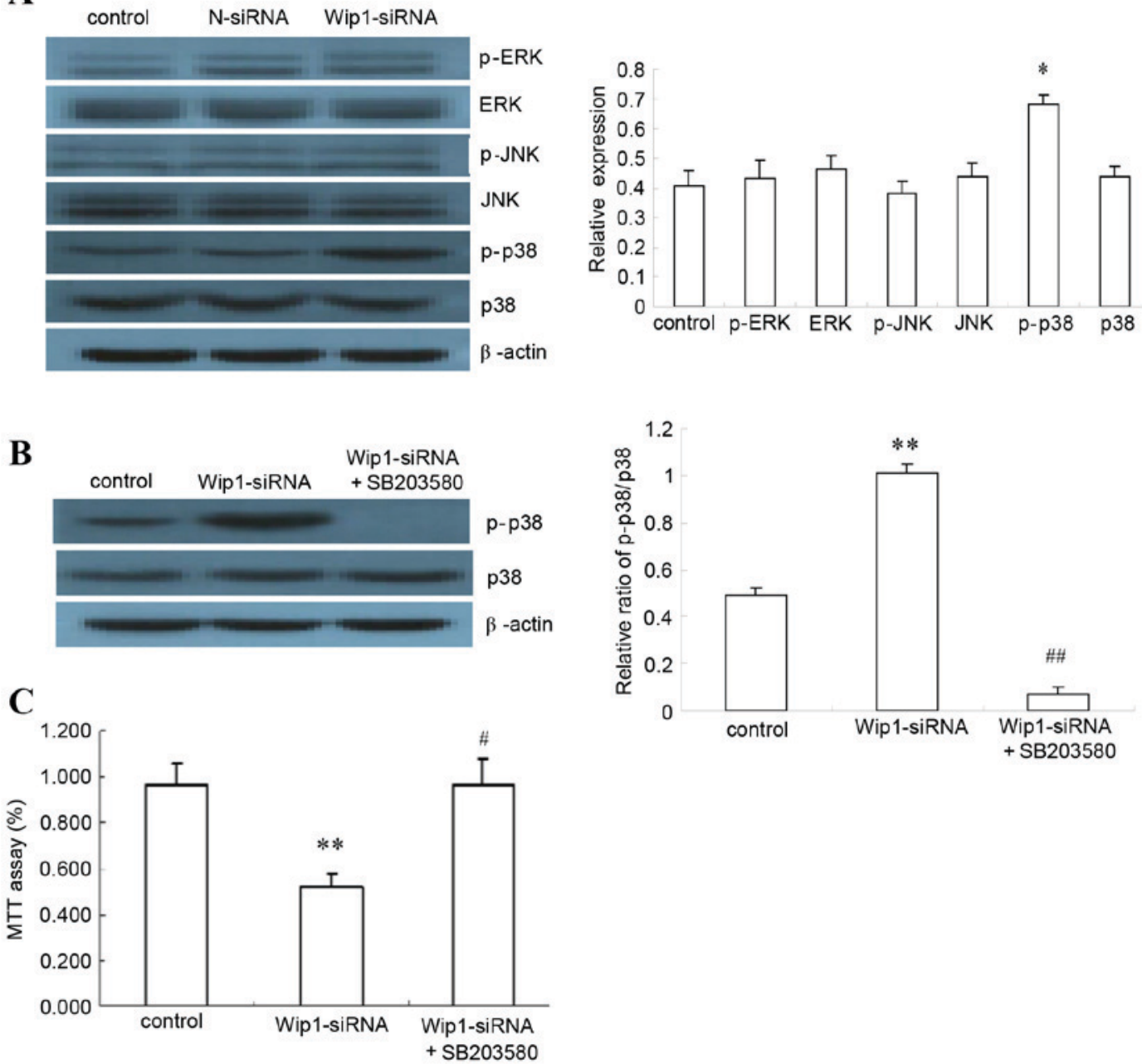

Figure 5. Effects of p38 MAPK inhibitor on Wip1-silenced SKOV3 cells. (A) SKOV3 cells were either left untransfected (Control, SKOV3 cells), or were transfected with N-siRNA or Wip1-siRNA. The protein expression of p-p38 MAPK, p38 MAPK, p-ERK, ERK, p-JNK and JNK were analyzed by western blot $(n=6)$. Representative images and quantification are reported here, as relative level to $\beta$-actin. (B) Effects of p38 MAPK and p-p38 MAPK were analyzed by western blot, following transfection with Wip1 siRNA and treatment with p38 MAPK inhibitor SB203580 for $48 \mathrm{~h}(10 \mu \mathrm{M})(\mathrm{n}=6)$. Representative images and quantification are reported here, as the ratio of p-p38/p38. (C) The proliferation rate of SKOV3 cells was analyzed by MTT assay, following transfection with Wip1 siRNA and treatment with p38 MAPK inhibitor SB203580 for $48 \mathrm{~h}(10 \mu \mathrm{M})(\mathrm{n}=4)$. Results are plotted as \% ratio relative to control (SKOV3 cells). ${ }^{*} \mathrm{P}<0.05$ and ${ }^{* *} \mathrm{P}<0.01$ vs. Control (SKOV3 cells). ${ }^{\#} \mathrm{P}<0.01$ and ${ }^{\# \#} \mathrm{P}<0.01$ vs. Wip1-siRNA. Wip1, wild-type p53-induced phosphatase 1 ; siRNA, small interfering RNA; N-siRNA, non-targeting siRNA; p-, phosphorylated; p38 MAPK, p38 mitogen-activated protein kinase; ERK, mitogen-activated protein kinase 1; JNK, mitogen-activated protein kinase 8 .

indicated that the apoptosis inhibiting effect of Wip1 could be reverted by its inhibitors. In a Mn neurotoxicity study by Ma et al (8), Wip1 expression in the neurons of Mn-exposed rats was progressively decreased, whereas p53 level and $\mathrm{Bax} / \mathrm{Bcl}-\mathrm{XL}$ ratio were elevated progressively, suggesting that Wip1 downregulation might induce apoptotic cell death. Another study also demonstrated a close association between Wipl expression and apoptosis: In HeLa cells, knockdown of Wip1 significantly decreased growth and colony formation ability and increased apoptosis, as evident also by a significant increase in the protein expression levels of p-p38 MAPK, p53, and p-p53 (26). By contrast, Goloudina et al (27) demonstrated that overexpression of Wip1 in p53-negative tumor cells activated the apoptotic pathway through increased Bax/Bcl-XL ratio, thereby leading to cancer cell apoptosis. The present study demonstrated that Wip1 silencing promoted apoptosis in SKOV3 ovarian cancer cells and upregulated caspase-3 expression and $\mathrm{Bax} / \mathrm{Bcl}-2$ ratio.
The MAPK signaling pathway is an important intracellular signaling system, and is involved in cell growth, development and apoptosis. The p38 MAPK signaling pathway directly phosphorylates the key regulator $\mathrm{p} 53$, which activates cell cycle arrest. In addition, activation of the p38 MAPK pathway is essential for drug-induced tumor cell death. Holnes et al (28) have studied the mechanism of vitamin A as a drug for ovarian cancer, and demonstrated that CD437 (a synthetic analog for vitamin A) induces CAOV3 cell apoptosis through the p38 MAPK pathway, and p38 MAPK antagonists could block this effect. Arsenic trioxide (ATO), a potential cancer chemotherapeutic drug, is known to have a curative effect on acute promyelocytic leukemia $(29,30)$. Yoda et al (31) confirmed that ATO induces phosphorylation of checkpoint kinase 2 (Chk2) and p38 MAPK and activates the p38 MAPK/p53 pathway, thus leading to apoptosis. Wipl was demonstrated to suppress DNA damage-induced phosphorylation of Chk2 and p38 MAPK in vitro, an effect that was restored by ATO treatment. 
Following suppression of Wip1 expression, ATO-induced activation of the p38 MAPK apoptotic pathway was significantly enhanced (31). Wip1 was therefore identified as a direct target of ATO in repression of tumor cell apoptosis. In the present study, silencing Wip1 significantly enhanced p38 MAPK phosphorylation, suggesting that Wip1 acts through the p38 MAPK pathway.

In conclusion, silencing Wip1 promoted apoptosis in SKOV3 ovarian cancer cells, most likely by promoting activation of the p38 MAPK signaling pathway. Therefore, Wip1 may be a potential therapeutic target in ovarian cancer.

\section{Acknowledgements}

This study was supported by the Key Project of Hebei Provincial Health and Family Planning Commission Fund (grant no. 20150204).

\section{References}

1. Jemal A, Bray F, Melissa M, Ferlay J, Ward E and Forman D Global cancer statistics. CA Cancer J Clin 61: 69-90, 2011.

2. Chen Y, Bieber MM and Teng NN: Hedgehog signaling regulates drug sensitivity by targeting $\mathrm{ABC}$ transporters $\mathrm{ABCB} 1$ and ABCG2 in epithelial ovarian cancer. Mol Carcinog 53: 625-634, 2014.

3. Zhang P, Jia R, Ying L, Liu B, Qian G, Fan X and Ge S: WWOX-mediated apoptosis in A549 cells mainly involves the mitochondrial pathway. Mol Med Rep 6: 121-124, 2012.

4. Fiscella M, Zhang H, Fan S, Sakaguchi K, Shen S, Mercer WE, Vande Woude GF, O'Connor PM and Appella E: Wip1, a nove human protein phospahtase that is induced in response to ionizing radiation in a p53-dependent manner. Proc Natl Acad Sci USA 94: 6048-6053, 1997.

5. Hirasawa A, Saito-Ohara F, Inoue J, Aoki D, Susumu N, Yokoyama T, Nozawa S, Inazawa J and Imoto I: Association of 17q21-q24 gain in ovarian clear cell adenocarcinomas with poor prognosis and identification of PPM1D and APPBP2 as likely amplification targets. Clin Cancer Res 9: 1995-2004, 2003

6. Richter M, Dayaram T, Gilmartin AG, Ganji G, Pemmasani SK, Van Der Key H, Shohet JM, Donehower LA and Kumar R: WIP1 phosphatase as a potential therapeutic target in neuroblastoma. PLoS One 10: e0115635, 2015.

7. Tang YL, Liu X, Gao SY, Feng H, Jiang YP, Wang SS, Yang J, Jiang J, Ma XR, Tang YJ, et al: WIP1 stimulates migration and invasion of salivary adenoid cystic carcinoma by inducing MMP-9 and VEGF-C. Oncotarget 6: 9031-9044, 2015.

8. Ma X, Han J, Wu Q, Liu H, Shi S, Wang C, Wang Y, Xiao J, Zhao J, Jiang J and Wan C: Involvement of dysregulated Wip1 in manganese-induced p53 signaling and neuronal apoptosis. Toxicol Lett 235: 17-27, 2015.

9. Sun GG, Zhang J, Ma XB, Wang YD, Cheng YJ and Hu WN: Overexpression of Wild-Type $\mathrm{p} 53$-Induced Phosphatase 1 confers poor prognosis of patients with Nasopharyngeal Carcinoma. Pathol Oncol Res 21: 283-291, 2015.

10. Sun GG, Wang YD, Liu Q and Hu WN: Expression of Wipl in kidney carcinoma and its correlation with tumor metastasis and clinical significance. Pathol Oncol Res 21: 219-224, 2015.

11. Livak KJ and Schmittgen TD: Analysis of relative gene expression data using real-time quantitative PCR and the 2(-Delta Delta C(T)) Method. Methods 25: 402-408, 2001.

12. Lee JS, Park JR, Kwon OS, Kim H, Fornace AJ Jr and Cha HJ: Off-target response of a Wip1 chemical inhibitor in skin keratinocytes. J Dermatol Sci 73: 125-134, 2014.

13. Yang DH, He JA, Li J, Ma WF, Hu XH, Xin SJ and Duan ZQ: Expression of proto-oncogene Wip1 in breast cancer and its clinical significance. Zhonghua Yi Xue Za Zhi 90: 519-522, 2010

14. Li J, Yang Y, Peng Y, Austin RJ, van Eyndhoven WG, Nguyen KC, Gabriele T, McCurrach ME, Marks JR, et al: Oncogenic properties of PPM1D located within a breast cancer amplification epicenter at 17q23. Nat Genet 31: 133-134, 2002.
15. Bulavin DV, Demidov ON, Saito S, Kauraniemi P, Phillips C, Amundson SA, Ambrosino C, Sauter G, Nebreda AR, Anderson CW, et al: Amplification of PPM1D in human tumors abrogates p53 tumor-suppressor activity. Nat Genet 31: 210-215, 2002 .

16. Rauta J, Alarmo EL, Kauraniemi P, Karhu R, Kuukasjärvi T and Kallioniemi A: The serine-threonine protein phosphatase PPM1D is frequently activated through amplification in aggressive primary breast tumours. Breast Cancer Res Treat 95: 257-263, 2006.

17. Fuku T, Semba S, Yutori H and Yokozaki H: Increased wild-type p53-induced phosphatase 1 (Wip1 or PPM1D) expression correlated with downregulation of checkpoint kinase 2 in human gastric carcinoma. Pathol Int 57: 566-571, 2007.

18. Castellino RC, De Bortoli M, Lu X, Moon SH, Nguyen TA, Shepard MA, Rao PH, Donehower LA and Kim JY: Medulloblastomas overexpress the p53-inactivating oncogene WIP1/PPM1D. J Neurooncol 86: 245-256, 2008.

19. Ehrbrecht A, Müller U, Wolter M, Hoischen A, Koch A, Radlwimmer B, Actor B, Mincheva A, Pietsch T, Lichter P, et al: Comprehensive genomic analysis of desmoplastic medulloblastomas: Identification of novel amplified genes and separate evaluation of the different histological components. J Pathol 208: 554-563, 2006.

20. Mendrzyk F, Radlwimmer B, Joos S, Kokocinski F, Benner A, Stange DE, Neben K, Fiegler H, Carter NP, Reifenberger G, et al: Genomic and protein expression profiling identifies CDK6 as novel independent prognostic marker in medulloblastoma. J Clin Oncol 23: 8853-8862, 2005.

21. Saito-Ohara F, Imoto I, Inoue J, Hosoi H, Nakagawara A, Sugimoto T and Inazawa J: PPM1D is a potential target for $17 \mathrm{q}$ gain in neuroblastoma. Cancer Res 63: 1876-1883, 2003.

22. Tan DS, Lambros MB, Rayter S, Natrajan R, Vatcheva R, Gao Q, Marchiò C, Geyer FC, Savage K, Parry S, et al: PPM1D is a potential therapeutic target in ovarian clear cell carcinomas. Clin Cancer Res 15: 2269-2280, 2009.

23. Lowe J, Cha H, Lee MO, Mazur SJ, Appella E and FornaceA J Jr: Regulation of the Wip1 phosphatase and its effects on the stress response. Front Biosci (Landmark Ed) 17: 1480-1498, 2012.

24. Zhang XP, Liu F and Wang W: Two-phase dynamics of p53 in the DNA damage response. Proc Natl Acad Sci USA 108: 8990-8995, 2011.

25. Song JY, Ryu SH, Cho YM, Kim YS, Lee BM, Lee SW and Choi J: Wip1 suppresses apoptotic cell death through direct dephosphorylation of BAX in response to $\gamma$-radiation. Cell Death Dis 4: e744, 2013.

26. Wang HY, Liu ZS, Qiu L, Guo J, Li YF, Zhang J, Wang TJ and Liu XD: Knockdown of Wipl enhances sensitivity to radiation in hela cells through activation of p38 MAPK. Oncol Res 22: 225-233, 2014.

27. Goloudina AR, Mazur SJ, Appella E, Garrido C and Demidov ON: Wip1 sensitizes p53-negative tumors to apoptosis by regulating the Bax/Bcl-xL ratio. Cell Cycle 11: 1883-1887, 2012.

28. Holnes WF, Soprano DR and Soprano KJ: Early events in the induction of apoptosis in ovarian carcinoma cells by CD437: Activation of the p38 MAP kinase signal pathway. Oncogene 22: 6377-6386, 2003.

29. Tallman M, Lo-Coco F, Barnes G, Kruse M, Wildner R, Martin M, Mueller U and Tang B: Cost-effectiveness analysis of treating acute promyelocytic leukemia patients with arsenic trioxide and retinoic acid in the United States. Clin Lymphoma Myeloma Leuk 15: 771-777, 2015.

30. Shepshelovich D, Oniashvili N, Parnes D, Klein A, Muchtar E, Yeshaya J, Aviram A, Rabizadeh E and Raanani P: Acute promyelocytic leukemia with isochromosome 17q and cryptic PML-RARA successfully treated with all-trans retinoic acid and arsenic trioxide. Cancer Genet 208: 575-579, 2015.

31. Yoda A, Toyoshima K, Watanabe Y, Onishi N, Hazaka Y, Tsukuda Y, Tsukada J, Kondo T, Tanaka Y and Minami Y: Arsenic trioxide augments Chk2/p53-mediated apoptosis by inhibiting oncogenic Wip1 phosphatase. J Biol Chem 283: 18969-18979, 2008. 